\title{
Physico-Chemical Characterization of Aonla Fruits Grown under Bengaluru Conditions
}

\author{
M.R. Chiranjeevi, B.M. Muralidhara ${ }^{*}$, Shivanand Hongal and M.K. Sneha \\ Department of Fruit Science, Post Graduate Centre, GKVK Campus, \\ Bengaluru-560 065, Karnataka, India \\ *Corresponding author
}

\section{A B S T R A C T}

\section{Keywords}

Aonla, Varieties, Fruit weight, Pulp per cent and ascorbic acid

Article Info

Accepted:

28 February 2018

Available Online:

10 March 2018
Aonla is one of the nutritive fruit crops and is well known as richest source of Vitamin-C content. The present experiment was conducted to evaluate the performance of six different varieties of Aonla for physico-chemical characteristics under Bengaluru condition. The results revealed that, significant variability was observed among the varieties for different fruit, seed and biochemical traits. The variety Krishna recorded maximum fruit length $(3.82 \mathrm{~cm})$, fruit diameter $(4.22 \mathrm{~cm})$, fruit weight $(49.33 \mathrm{~g})$ and pulp weight (41.1 g). Maximum pulp content (84.75\%) and pulp to stone ratio (5.65) was recorded in NA-10 and Krishna varieties, respectively. The maximum stone weight $(7.7 \mathrm{~g})$, seeds per fruit $(6.6)$ and seed length $(0.54 \mathrm{~cm})$ was recorded highest in Kanchan variety. Ascorbic acid content in fruit pulp $(564.4 \mathrm{mg} / 100 \mathrm{~g})$ was highest in Krishna variety. The variety Krishna was found superior compared to other varieties for fruit characters and ascorbic acid content.

\section{Introduction}

Aonla also known as Indian goseberry (Emblica officinalis Gaertn.) is indigenous to Indian subcontinent. Owing to its hardy nature, sustainability to various wastelands and high productivity, it has high production potential with low maintenance cost and enormous therapeutic and nutritive values. Therefore, it is predicted to be "fruit of $21^{\text {st }}$ century".

The fruit is used as a major constituent in several ayurvedic preparations such as Chavanprash and Rasayana which promotes health and longevity (Rajkumar et al., 2001).
Aonla is one of the richest natural sources of Vitamin C. In addition to this, potent antioxidants, several active tannoid principles have been identified which appear to account for its health benefits (Rastogi, 1993).

Aonla has been reported to posses expectorant, purgative, spasmolytic, antibacterial, hypoglycemic (Jayshri and Jolly, 1993), hepatoprotective and hypolipidemic (Thakur and Mandal, 2004) activity.

The present work was carried out to see the performance of different varieties for various physico-chemical characteristics under Bengaluru condition. 


\section{Materials and Methods}

The fruits were collected from the Aonla orchard located at Regional Horticultural Research and Extension Centre, University of Horticultural Sciences campus, Vidyaranyapura Bengaluru. The fully matured fresh fruits were harvested and used for the study of fruit and seed parameters. The varieties studied are NA-6, NA-7, NA-10, Krishna, Kanchan, and Chakaiya. The fruit weight $(\mathrm{g})$, fruit length $(\mathrm{cm})$, pulp weight $(\mathrm{g})$, stone weight $(\mathrm{g})$, pulp to stone ratio, pulp per cent, seed weight, number of seeds per fruit, length of the seeds, breadth of the seeds were recorded. The ascorbic acid content was estimated by 2,6 , dichlorophenol indophenols titration method as recommended by Ranganna (1986) and expressed in terms of milligrams per hundred grams of fruit. Ascorbic acid was calculated using the formula.

Titre value $\mathrm{x}$ dye factor $\mathrm{x}$ volume made up Ascorbic acid (mg/100 g) = ----------- x100

Aliquot of extract taken $\mathrm{x}$ volume of sample

\section{Statistical analysis}

The experimental values were analyzed statistically by using completely randomized block design (CRD) with three replications of each cultivar. Means were compared using WASP (WEB Agri Stat Package ICAR Research Complex, Goa) test at 5\% level of significance.

\section{Results and Discussion}

The variability was observed for fruit characters in different varieties of aonla and presented in Table 1. The fruit length varied from $3.65 \mathrm{~cm}$ in NA-6 to $3.82 \mathrm{~cm}$ in Krishna. The difference in fruit length may be due to its genetic factors. Teotia et al., (1968) reported that the fruit length of Banarasi and Chakaiya varieties of aonla was $3.74 \mathrm{~cm}$ and $3.20 \mathrm{~cm}$, respectively. The maximum fruit diameter was recorded in Krishna $(4.22 \mathrm{~cm})$ which is on par with Kanchan $(4.17 \mathrm{~cm})$ and $\mathrm{N}-10(4.12 \mathrm{~cm})$ and minimum was in NA-7 $(3.82 \mathrm{~cm})$. It was observed that the diameter of fruit was found to be always greater than the length of aonla fruit. From the present investigation it can be remarked that, length and breadth of fruits are highly variable traits. Similar variation in fruit diameter was noticed in pummelo (Narayanmurthy, 1982) and date palm (Muralidhara et al., 2016).

The cultivar Krishna was characterized with higher fruit weight $(49.33 \mathrm{~g})$ which was significantly superior over all other varieties. The minimum fruit weight was recorded in NA-6 (33.85 g). The genetic variability, climatic factors and management may be the main reason for variation in fruit weight in aonla (Ghosh et al., 2003 and Sanjeev and Singh, 2002).

The present investigation also revealed that the variety Krishna had the highest pulp weight $(41.10 \mathrm{~g})$ and the lowest pulp weight was found in NA-6 (28.13 g). This may be due to the fact that basically the weight and size of fruits contributed to the pulp weight. In the same manner, variation in pulp weight was reported in jack fruit (Guruprasad, 1981) and jamun (Singh et al., 2007).

There was no significant difference for the pulp per cent among different aonla varieties. However maximum pulp per cent was recorded in NA-10 $(84.75 \%)$ and minimum was in Kanchan (77.94 \%). The results are in agreement with Singh and Arora (1967) who reported that, the percent pulp portion was 86 and 90.7 per cent in Banarasi and Chakaiya varieties of aonla respectively. Other studies in aonla (Chaudhari et al., 1995) and ber (Gujarathi et al., 1992) have indicated similar results. 
Table.1 Characterization of different varieties of Aonla for fruit morphology

\begin{tabular}{|l|l|l|l|l|l|l|}
\hline Varieties & $\begin{array}{l}\text { Fruit } \\
\text { length } \\
(\mathrm{cm})\end{array}$ & $\begin{array}{l}\text { Fruit } \\
\text { diameter } \\
(\mathrm{cm})\end{array}$ & $\begin{array}{l}\text { Fruit } \\
\text { weight }(\mathrm{g})\end{array}$ & $\begin{array}{l}\text { Pulp } \\
\text { weight (g) }\end{array}$ & $\begin{array}{l}\text { Pulp } \\
\text { percent } \\
(\%)\end{array}$ & $\begin{array}{l}\text { Pulp to } \\
\text { stone ratio }\end{array}$ \\
\hline NA-6 & 3.65 & 3.94 & 33.85 & 28.13 & 83.1 & 5.11 \\
\hline NA-7 & 3.72 & 3.82 & 42.33 & 35.41 & 83.65 & 5.42 \\
\hline NA-10 & 3.69 & 4.12 & 37.52 & 31.8 & 84.75 & 5.21 \\
\hline Krishna & 3.82 & 4.22 & 49.33 & 41.1 & 83.31 & 5.65 \\
\hline Kanchan & 3.77 & 4.17 & 41.39 & 32.26 & 77.94 & 4.18 \\
\hline Chakaiya & 3.69 & 4.08 & 39.42 & 32.21 & 81.7 & 5.25 \\
\hline F test & $*$ & $*$ & $*$ & $*$ & NS & $*$ \\
\hline SEm \pm & 0.02 & 0.08 & 0.96 & 0.48 & 2.06 & 0.17 \\
\hline CD $(\mathbf{0 . 0 5})$ & $\mathbf{0 . 0 6}$ & $\mathbf{0 . 2 4}$ & $\mathbf{2 . 8 8}$ & $\mathbf{1 . 4 5}$ & NS & $\mathbf{0 . 5 1}$ \\
\hline
\end{tabular}

Table.2 Characterization of different varieties of Aonla for seed characters and ascorbic acid

\begin{tabular}{|l|l|l|l|l|l|l|}
\hline Varieties & $\begin{array}{l}\text { Stone weight } \\
(\mathrm{g})\end{array}$ & $\begin{array}{l}\text { Seeds } \\
\text { fruit }\end{array}$ & $\begin{array}{l}\text { Seed weight } \\
\text { per fruit }(\mathrm{g})\end{array}$ & $\begin{array}{l}\text { Seed } \\
(\mathrm{cm})\end{array}$ & length & $\begin{array}{l}\text { Vitamin C } \\
(\mathrm{mg} / \mathbf{1 0 0 g})\end{array}$ \\
\hline NA-6 & 5.5 & 6 & 0.13 & 0.45 & 451.2 \\
\hline NA-7 & 6.53 & 6 & 0.1 & 0.45 & 482.3 \\
\hline NA-10 & 6.1 & 6 & 0.11 & 0.46 & 523.3 \\
\hline Krishna & 7.27 & 6.6 & 0.14 & 0.51 & 564.4 \\
\hline Kanchan & 7.7 & 6.6 & 0.13 & 0.54 & 519.3 \\
\hline Chakaiya & 6.13 & 6 & 0.11 & 0.47 & 535.7 \\
\hline F test & $*$ & $*$ & $*$ & $*$ & $*$ \\
\hline SEm \pm & 0.23 & 0.19 & 0.01 & 0.02 & 3.61 \\
\hline CD $(\mathbf{0 . 0 5})$ & $\mathbf{0 . 6 9}$ & $\mathbf{0 . 5 7}$ & $\mathbf{0 . 0 3}$ & $\mathbf{0 . 0 6}$ & $\mathbf{1 0 . 8 3}$ \\
\hline
\end{tabular}

The maximum pulp to stone ratio was recorded in Krishna (5.65) and minimum was in Kanchan (4.18). The difference in pulp to stone ratio may be due to its genetic differences, weight and size of fruits, and weight and size of stone. Chaudhari et al., (1995) have reported similar results in aonla.

The variability observed for seed characters in different varieties of aonla are presented in table 2. The highest stone weight was observed in Kanchan (7.70 g) while least stone weight was recorded in NA-6 with 5.50 g. Such variation in stone weight was probably due to inherent variation in fruit. Similar observation was made in ber
(Gujarathi et al., 1992). The maximum seed weight per fruit was recorded in Kanchan $(0.14 \mathrm{~g})$ while minimum was recorded in NA$7(0.10 \mathrm{~g})$. The differences in seed weight per fruit in aonla may be attributed to the differences in number and size of seeds (Chaudhari et al., 1995). The maximum number of 6.6 seeds per fruit was recorded in Kanchan and Krishna (Table 2). The similar results were reported in kokum seedling types (Khanvilkar et al., 1986). Maximum seed length was recorded in Kanchan $(0.54 \mathrm{~cm})$ which, was on par with Krishna $(0.51 \mathrm{~cm})$. The Maximum seed length was recorded in Kanchan $(0.54 \mathrm{~cm})$ whereas, minimum length of seed was observed in NA-6 $(0.45 \mathrm{~cm})$ and 
NA-7 $(0.45 \mathrm{~cm})$. Similar difference in seed length and thickness were recorded by David (1907) in tamarind.

Among the different varieties, the ascorbic acid content (Table 2) was highest in variety Krishna (564.40 mg/100g) and the lowest was recorded in NA-6 $(451.20 \mathrm{mg} / 100 \mathrm{~g})$. The variation in ascorbic acid content of different varieties may also be attributed due to genetic character and varietal differences in aonla (Sanjeev and Singh, 2002). The results revealed that, significant variability was observed among the varieties for different fruit, seed and biochemical traits. In conclusion, the variety Krishna was found superior in comparison to other varieties for fruit characters and ascorbic acid content.

\section{References}

Chaudhari, S.M., Sheje, M.B. and Desai, U.T., Seedling selection in aonla. J. Maharashtra Agri. Sci., 20(1): 140 (1995).

David, H.F.C.S., The uses and composition of tamarind seeds. The Agric. ledger, 2:13-16 (1907).

Ghosh, S. N., Mathew, B. and Manna, S., Evaluation of some aonla cultivars in West Bengal. J. Interacad., 7(1): 21-24 (2003).

Gujarathi, R.T., Wavhal, K.N. and Masaikar, S.D., Evalution of germplasm of ber (Ziziphus Mauritiana) for physicchemical characteristics of fruit, Maharashtra J. Hort., 6(1):13-16. (1992).

Guruprasad, T. R., Studies on systematic selection of jack fruit (Artocarpus heterophyllus) types. M.Sc (Hort.) Thesis, submitted to University Agricultural Science., Bangalore. (1981).

Jayshri, S. and Jolly C. I., 1993, Phytochemical antibacterial and pharmacological investigations on Monordica chiranlia and Emblica officinalis. Ind. J. Pharm. Sci., 1: 6-13 (1993).

Khanvilkar, S.V., Salvi, M.J. and Joshi, G.D., Studies on certain strains of Kokum seedlings for yield and fruit characters. J. Maharashtra Agri. Sci., 11(2):174-175 (1986).

Muralidhara, B.M., Singh R.S., Bhargava, R. Veena, G.L. and Mahanthi Kishor Kumar, Morphological characterization of date fruits at different growth stages under hot arid conditions. Env., \& Eco., 34(4):1234-1237 (2016).

Narayanamurthy, R., studies on systematic evaluation of productive pummel of seedling type. M.Sc. (Hort.) Thesis, submitted to University Of Agriculture Science., Bangalore. (1982).

Rajkumar, N. V, Theres, M. and Kuttan, R., Emblica officinalis fruits afford protection against experimental gastric ulcers in rats. Pharmaceut. Biol., 39(5):375-380 (2001).

Ranganna, S., Manual of analysis of fruits and vegetable products, Tata McGraw Hill publishing Co. Ltd., New Delhi, pp 441- 495 (1986).

Rastogi, R. P., Compendium of Indian Medicinal plants, CDRI, Lucknow and ID, New Delhi, 1: 530 (1993).

Sanjeev K. and Singh, I.S., Physicochemical studies on various cultivars of aonla fruits. Prog Hort., 34: 102-104 (2002).

Singh, A.K., Anju, B., Achal, S., Anurag, S. and Reddy, B. M.C., 2007, Evaluation of variability in jamun (Syzygium cuminii) using morphological and physico-chemical characterization. Ind. J. Agri. Sci., 77(12): 845-848.

Singh, J.R. and Arora, J.S., Physico-chemical difference in two varieties of aonla (Phyllanthus emblica) at maturity. Punjab Hort. J., 6:145-146 (1967).

Teaotia, S.S., Singh, D.B., Singh, R.D. and 
Singh, R.N., Studies of some important varieties of aonla of Eastern Uttar Pradesh. Punjab Hort J., 8(4):241-244 (1968).

Thakur C. P. and Mandal K., Effect of Emblica officinalis on cholesterol induced atherosclerosis in rabbits. Ind. J. Med. Res., 79:142-146 (1984).

Vinayagamoothy, T., Antibacterial activity of some medicinal plants of Srilanka Ceylon. J. Sci. Biol., 11: 50-55 (1982).

\section{How to cite this article:}

Chiranjeevi, M.R., B.M. Muralidhara, Shivanand Hongal and Sneha, M.K. 2018. PhysicoChemical Characterization of Aonla Fruits Grown under Bengaluru Conditions. Int.J.Curr.Microbiol.App.Sci. 7(03): 3611-3615. doi: https://doi.org/10.20546/ijcmas.2018.703.416 